\title{
ELT course books and Global English: the case of Greek lower secondary state schools
}

\author{
Livros de curso de ELT e inglês global: o caso das escolas do ensino médio do ensino \\ médio grego
}

\author{
Natasha Tsantila* \\ Hellenic Open University \\ American College of Greece \\ Athens, Grécia \\ Anastasia Georgountzou ** \\ University of Athens \\ Hellenic Open University \\ Athens, Grécia
}

\begin{abstract}
This article investigates whether aspects of Global English (GE) are echoed in textbooks used in the English classes of Greek lower secondary state schools. Given that English is no longer another foreign language but the world lingua franca, we argue that ELT students should be prepared to cope with the international, diversified linguacultural demands. Since listening is associated with intelligibility and comprehensibility, issues of utmost importance for effective communication of the messages conveyed, we conducted an analysis of the listening components of two main textbook series, Think Teen. Findings indicate that despite the variety of topics and their relevance to the learners' needs and interests as observed in the audios, there is a limited amount of authenticity and genuineness. What's more, there was an over-reliance on British English (BrE) Standard accent and a lack of well- structured tasks rendering learners unable to reflect upon the realistic use of English, permeating thus British-bound stereotypes and attitudes among them. Finally, we recommend that ELT listening materials be adequately modified so that the global reality is represented. A recommendation of a potential adaptation of a specific listening section included in one of the two textbooks is provided.
\end{abstract}

Keywords: Global English, ELF/EIL, ELT materials.

Resumo: O objetivo deste artigo é investigar se aspectos do Inglês Global (IG) ecoam em livros didáticos usados nas salas de aula de escolas públicas secundárias da Grécia. Diante do fato que o inglês não é apenas mais uma língua estrangeira, mas a língua franca do mundo, defendemos que aprendizes dessa língua devem ser preparados para lidarem com as diferentes demandas linguísticoculturais em nível internacional. Uma vez que a habilidade de compreensão oral (listening) está diretamente associada com inteligibilidade e compreensibilidade, questões de grande importância para a comunicação efetiva das mensagens enviadas, conduzimos uma análise deste componente em dois livros de uma série didática, Think Teen. Os resultados indicam que, apesar de variedade de tópicos e a sua relevância para as necessidades e interesses dos estudantes, como observado nos

* Professora do American College of Greece, Athens, \& Hellenic Open University, Patras, Greece. Email: ntsantila@acg.edu.

** Professor da School of Philosophy, Faculty of English Language and Literature National and Kapodistrian University of Athens, Athens, \& Hellenic Open University, Patras, Greece. Email: stacegee1@hotmail.com. 
segmentos selecionados, há uma limitação no tocante à autenticidade e originalidade. Mais ainda, constata-se ênfase total no sotaque do Inglês Padrão Britânico (BrE) e uma falta de tarefas bem estruturadas no sentido de levar os alunos a refletir sobre o uso mais realístico da língua inglesa, abrindo, assim, espaço para estereótipos e atitudes voltados para o mundo britânico entre eles. Finalmente, recomendamos que os materiais de compreensão oral de língua inglesa sejam adequadamente modificados de modo que representem a realidade global. Como ilustração, o artigo traz uma recomendação de potencial adaptação de uma atividade de compreensão oral específica que faz parte de um dos dois livros analisados.

Palavras-chave: Inglês Global, ELF/EIL, materiais ELT.

\section{INTRODUCTION}

The extensive use of English worldwide by native $(\mathrm{N})$ and approximately two billion (CRYSTAL, 2008, p. 1; GRADDOL, 2006, p. 14) non-native speakers of English (NNSs) has established its changing role as the globally employed, "contact language" (FIRTH, 1996, p. 240) "among speakers of different first languages for whom English is the communicative medium of choice, and often the only option." (SEIDLHOFER, 2011, p. 7). This is well manifested in the various educational, socio-political, entrepreneurial and 'inter and intra migratory' contexts and interactions (interactions among the migrants themselves and between migrants with the local people of the host country) that followon from the continual socio-political and professional mobility as well as the migratory movements.

School settings are not left unaffected by this worldwide observed human mobility and relocation as most English classes, worldwide, consist of students coming from heterogeneous linguacultural backgrounds contributing, thus, indisputably even further to the necessity of integrating global aspects of English $\left(\mathrm{GE}^{1}\right)$ into current ELT settings. Such being the case, the pedagogical implications of this new reality are to be considered as it has been argued by ELF, EIL and WE researchers (i.e., JENKINS, 2006; MATSUDA, 2017; McKAY, 2003; SEIDLHOFER, 2001, 2011; VETTOREL; LOPRIORE, 2017). Consequently, teaching practices, practitioners' and learners' attitudes towards adopting a more liberal, intercultural view should be reflected upon and reconsidered accordingly so that the $21^{\text {st }}$ century ELT learners mature as global "users of English" (SEIDLHOFER, 2011), ready to negotiate and accommodate as per the circumstances, with other international interlocutors.

In light of the above and given the major changes that English has undergone over the last decades as well as the recent developments in ELF/EIL/WE research, the focus on ELT should shift from the "form", stressed in traditional ESOL contexts, to the "use" of the language, involving thus learners in real life

\footnotetext{
${ }^{1}$ Although we acknowledge the differences in the fields of ELF, EIL and WE, we use the term GE, in this paper, as an umbrella term to refer to any type of "interaction [among] people of different L1 backgrounds" (SIFAKIS, 2017).
} 
communication. In other words, pedagogical practices should be adapted moving from the "learner" and the "context of learning" to the "user" and the "context of use" since "the [1]earners of English as a foreign language assume the role of users of English as a lingua franca as they move into contexts of use outside the classroom" (SEIDLHOFER, 2011, p. 187)

Hence, since the latest ELT contexts are genuine GE contexts, it is fundamental that, before the adaptation and implementation of teaching practices and materials, ELT practitioners working in multicultural and multilingual contexts reflect upon the aforementioned challenges and rise to the global occasion. So eventually, after delving into the relevant and recent ELF/EIL/WEs and ELT literature, ESOLers "question some of the deeply rooted assumptions [they] hold about language" (PARK; WEE, 2011, p. 368), mainly revolving around the teaching of standard, inner-circle English. These teachers then should, as Seidlhofer (2008) argues, be ready to replace their heavily Inner Circle-bound "normative mind-set" (p. 33), make connections with their students' local and global needs, and ultimately, develop as "ELF [GE]-aware" (BAYYURT; SIFAKIS, 2015) pedagogues. Eventually, they will become knowledgeable and confident enough to evaluate whether the hitherto ELT practices and materials are appropriate to the demands of the global user, and relevant to their learners' needs.

\section{ELT COURSEBOOKS AND GE}

Teaching materials, coursebooks in particular, are essential tools for transferring "curricular knowledge" in the classroom and understanding of the subject. The ELT coursebooks and materials constitute "a unique case among other coursebooks" (DENDRINOS, 1992, p. 39) since "[they] are perceived by many to be the route map of any ELT programme" (SHELDON, 1988, p. 238) and are used by teachers as the main tools to assist learners to build on their linguistic and communicative abilities. Besides, ELT materials are mainly controlled and massively produced by large international publishing companies, (TOMLINSON, 2003) focusing largely on developing Inner-Circle linguistic (lexico-grammatic and phonological) accuracy among learners and promoting Inner Circle culture bound topics, disregarding, thus, the needs and interests of the international and global clientele they target at. What's more, even when local publishers and authors are involved in the development of ELT courseware, they heavily abide by the Inner Circle norms in alignment with the publishers' goal which is "commercial success" (DENDRINOS, 1992, p. 35). Therefore, although several recently published books seem to be directed towards a more global body of students by integrating issues of global interest (e.g., travel, environment, food), showing thus an attempt towards "deterritorialization in which the UK ceases to function as the main locus of action" (GRAY, 2010, p. 109), they still, pursuing the "commercial success", contain flaws and omissions regarding the global aspect of English.

These omissions are further corroborated by GE research and its interfaces with ELT. Truly, despite the implications of the vast and multifaceted GE research findings 
on the benefits of integrating them in the classrooms, published ELT materials still display a NSs dominance (i.e., JENKINS, 2007, p. 244), or a strong orientation towards Inner Circle and, in some cases, Outer Circle varieties (i.e., MATSUDA, 2002b; SIQUEIRA, 2015, TAKAHASHI, 2011; VETTOREL; LOPRIORE, 2013). Providing further evidence on the NS dominance in ELT materials, Tomlinson and Masuhara (2013), in an analysis aiming to evaluate the "long term effectiveness" (p. 234) of coursebooks, also indicate that the coursebooks under investigation focused primarily on British English and on "educated, middle-class British norms" (p. 244). They add that only in one of the books they analysed, The Big Picture, were there some instances of including ELF users in the coursebook but even in those cases, "the photos of foreign people make them seem like exotic beings rather than, possibly, ELF users" (p. 244).

The aforementioned tendency, however, even though extensively challenged in the last years (i.e., JENKINS, 2009; MATSUDA, 2012; SEIDLHOFER, 2011), is very restrictive and does not "prepare [learners] adequately to use English in the future with other [NNSs]" (MATSUDA, 2002b, p. 196), nor does it help them "understand that their future interlocutors may be not native speakers but non-native speakers just like themselves" (MATSUDA, 2002a, p. 439). As a result, "they [English language students] cannot fully take advantage of the opportunities that accompany the use of English as an international language" (MATSUDA 2002b, p. 184) and develop as effective global communicators.

More research in WEs and ELF has stressed the necessity to expose learners to outer and expanding circle varieties (i.e., FRIEDRICH, 2012; KIVISTÖ, 2005) and indeed, a more international perspective is now adopted in some ELT materials. For example, recent studies on ELT materials and ELF (i.e., CALEFFI, 2016; TAKAHASHI, 2011) indicate that ELF or EIL are gradually integrated in ELT materials. Such novel practices though seem to reflect mainly issues linked with the sociocultural aspects (VETTOREL; LOPRIORE, 2013) of English, as an international language of communication, and not linguistic ones. However, as learners of English need to be more effectively prepared for their future social, educational and employment encounters with other NNSs besides NSs ones, it is necessary that ELT coursebooks move away from Standard Inner Circle varieties and include NN and N regional varieties as well (i.e., KIRKPATRICK, 2009; MODIANO, 1999).

The aforementioned observations render the need for ELT textbook evaluation crucial as "the whole [socio]-educational setting in which the teaching [and learning] [are] to take place" (McDONOUGH; SHAW; MASUHARA, 2013, p. 21) is connected with learners and their global communicative needs. Consequently, since the various current socio-educational settings are beyond "the traditionally acknowledged point of reference of British English (and culture)" (VETTOREL; LOPRIORE, 2013, p. 485), tasks and activities included in the coursebooks would be designed to reflect the plurality, diversity, and "heterogeneity of [language and] contexts of use outside the classroom" (CALEFFI, 2016, p. 65). This way, language learners and prospective English language users can be exposed to real "de-territorialized speech events" 
(SEIDLHOFER, 2011, p. 4) in which they can understand that they can still "communicate within a certain functional realm despite their possible pronunciation, grammatical, vocabulary, cultural and rhetorical differences" (FRIEDRICH, 2012, p. 44). In other words, learners should be exposed to language practices related to GE aspects such as: a) accommodation strategies practiced among interlocutors, b) awareness-raising of the sociolinguistic complexity of Englishes (MATSUDA, 2002b), and c) promotion of cultural and intercultural awareness (SIFAKIS; SOUGARI, 2004) among learners.

This article attempts to contribute towards this direction. It explores whether and to what extent relevant research and findings in $\mathrm{GE}^{2}$, (i.e., GRAY, 2002; KACHRU, 1986; PRODROMOU, 1992; SEIDLHOFER, 2004; SIFAKIS; SOUGARI, 2005) reflecting Seidlhofer's "de-territorialized speech events" have been considered in the design of ELT coursebook, Think Teen, used in the $1^{\text {st }}$ grade of Greek secondary schools as per certain criteria outlined below. Findings are expected to lead to ELT implications towards: a) possible adaptations, if not reassessments of the existing materials, b) suggestions for a more effective use of the already existing tasks and hopefully, for more effective teaching, "not [necessarily] by [providing] definitive answers to pedagogical questions, but rather by providing new insights into the teaching and learning process" (McKAY, 2006, p. 1).

\section{THE GREEK CONTEXT}

Within the Greek state school system, English is a compulsory subject from grade 3 of the state primary school until grade 12 . Throughout the primary level, English is taught for three hours per week, whereas at the secondary level, it is taught for three hours in grades 7 and 10 respectively and two hours for the remaining (i.e., $8,9,11,12)$ grades. Learners are placed in classes according to their level of English language competency as it was recently announced, ratified and published in the Government gazette. (MINISTRY OF EDUCATION, AUGUST 2016). This decision is also reflected in the different levels of the Think Teen series since there are two books (beginners and advanced) used in the first two grades of lower secondary school.

The Think Teen series has been written by Greek authors and can be characterised as "being "local[ly]" produced in alignment with the local curriculum (BARRIOS, DE DEBAT, E. V.; TAVELLA, 2008; TSAGARI; SIFAKIS, 2014, p. 213). Previous relevant and recent research on Greek ELT materials has been conducted by Tsagari and Sifakis (2014) who evaluated the structure and effectiveness of courseware used in grades 4 and 5. Regarding Think Teen, previous research addresses issues of evaluation of the writing component of the $2^{\text {nd }}$ Grade textbook,

\footnotetext{
2 The studies reported in this section have been deliberately chosen to be till 2010, as the specific textbooks we examined were published in 2010 .
} 
Advanced (AZA, 2012), or the teaching of speaking materials of the $1^{\text {st }}$ Grade (advanced) coursebook of the series (HATZINIKOLAOU, 2014). No previous research, to our knowledge, has focused on the evaluation of the specific series in relation to GE.

Think Teen, used in lower secondary education, is provided by the Ministry of Education and was designed by the Pedagogic Institute in Greece. It consists of 5 coursebooks (two for grades 7 and 8 and one for grade 9), their workbooks and accompanying CDs and supplementary material. The two books of grades $7^{3}$ and 8 are designed for two levels, beginners and advanced learners, whereas no distinction is made for the grade 9 students. The "design and construction" of the courseware series, follows "the Common European Framework of Reference (2001) and the Cross-curricular Unified Framework (2003)(KARAGIANNI, et al, 2008; p. ii) aiming to reflect "the new order of reality in English language (i.e., plurilingualism and pluriculturalism) by: i) promoting learners' "communication strategies", as per their "needs and interests", ii) increasing intercultural awareness, iii) stimulating learners' motivation and iv) helping them become "autonomous" through the employment of "authentic and semi-authentic listening texts"(KARAGIANNI, et al, 2008; p. ii; p. viii). As it is described in the teacher's book, "listening texts are semi-scripted and include authentic features of oral discourse, such as false starts, hesitations and rephrasing" (KARAGIANNI, et al, 2008; p. 11). Besides as it is described in the state curriculum, learners are not required to reach near-native speaker proficiency. Instead, the emphasis is on the promotion of intelligibility and effective communication with NSs as well as NNSs drawing practitioners' attention thus to the international character of English. The above features are GE-related. In this respect, it is significant to investigate whether and to what extent GE-related aspects are reflected in the actual courseware as described above.

In this study, we focus on the evaluation of the two $1^{\text {st }}$ grade -that is grade 7 of lower secondary state coursebooks, one for beginners (henceforth B1) and one for advanced (henceforth B2) students. The specific books were selected on the basis of their exclusive use in the public sector and the main GE-related claims, as stated above, they make. What's more, due to the financial crisis, the particular materials are not expected to be replaced in the near future, so inclusion or exclusion of global features of English as a lingua franca and possible adaptation of the material seem of critical importance.

\section{THE STUDY}

The purpose of the study was to explore whether aspects of GE, as displayed in the listening inputs and activities of the aforementioned books, have been designed in a

\footnotetext{
${ }^{3}$ Grade 7 corresponds to $1^{\text {st }}$ grade of lower secondary school, whereas grade 8, refers to $2^{\text {nd }}$ grade of lower secondary education.
} 
manner that promotes issues of "pluriculturalism" "communication strategies", as per the learners' "needs and interests", authenticity, and intercultural awareness (KARAGIANNI et al, 2008, p. vii) in a world in which English is used as the lingua franca.

The focus of our analysis on listening was decided after we had delved into relevant research on GE and listening (i.e., GALLOWAY; ROSE, 2014; VANDERGRIFT, L.; GOH C.M C., 2012), acknowledging that the latter is connected with issues of intelligibility, accommodation and comprehensibility (JENKINS, 2000) rather than adherence to native speaker norms and accuracy. Consequently, it plays a critical part when learning a new language and, ultimately, in effective communication.

\subsection{RESEARCH QUESTIONS}

For the purpose of this study, the following research questions were agreed upon:

1. Do the Think Teen textbooks currently used in the Greek $1^{\text {st }}$ grade of secondary schools reflect aspects of GE through the listening input skills and related tasks?

2. Do the Think Teen textbooks currently used in the Greek $1^{\text {st }}$ grade of secondary schools prepare students to function effectively, in authentic communication situations, at a global as well as a local level?

3. To which extent are the global aspects proclaimed in the teacher's book in reference to the listening component consistent with the student' package?

\subsection{CRITERIA AND RATIONALE}

Our aim was to explore whether the several pedagogical concerns and implications that had been raised in the GE research until 2008, the year of publication of the specific series, (i.e., JENKINS, 2006; KIVISTÖ, 2005; McKAY, 2003; MATSUDA, 2002b, SEIDLHOFER, 2001; SIFAKIS, 2004; SIFAKIS; SOUGARI, 2005) as well as in textbook evaluation (i.e., GRAY, 2002; TOMLINSON, 2003) have been taken into account in the design of the listening component of B1 and B2. To answer our research questions, we established the criteria below, accompanied by definitions, where necessary, and reasons we have opted for them. These criteria, derived from (McKAY 2012; SIFAKIS; GEORGOUNTZOU; HILL, 2004; TOMLISON; MASUHARA, 2013), were thought to be the most relevant for the specific study since we aimed at investigating the kind of language input and supporting activities regarding the heterogeneity, plurality and diversity of GE.

\subsubsection{Criterion 1: Direct or indirect exposure to aspects of GE as manifested through:}

\section{a) the variety of:}

\section{- topics/relevance,}

As per the relevant literature in ELT (i.e., DAY et al, 2009; McDONOUGH et al, 2013; ROST, 2016), the topics selected in ELT materials must be engaging and relevant to the learners' age, interests, needs, probably their learning styles and reflect a wide variety of global issues, such as environment, travel, music, sports, traditions etc. because it is through the topic variety and relevance to learners' needs that the learners' curiosity and attention are aroused and engagement with critical reflection is encouraged (McGRATH, 
2013). In case of a GE context, "course books should also provide opportunities to encourage learners to critically engage with the content" (GALLOWAY, 2017, p. 476), [and] to consider the role of English in their own context" (GALLOWAY, 2017, p. 478) as well as the role of English as a global lingua franca.

- accents

By having learners exposed to different speech varieties, their "attention is not placed on a specific variety" but [...] on how to overcome the different linguistic barriers that may emerge when communicating with others" (CAVALHEIRO, 2014). Thus, they can improve their understanding when exposed to other linguistic varieties "within the English language" and eventually familiarise themselves with "other cultures as well (p. 75)

- genres

The selection of listening texts, of various linguistic structures closely connected with the situation these texts are used, is crucial and linked to factors such as, interest, backgrounds, talents and expectations, entertainment, cultural accessibility of the listening text and speaker roles and intentions (MILLER, 1984; ROST, 2016). Consequently, different and suitable listening texts, such as interviews, broadcasts, presentations, discussions between peers, etc., help the $21^{\text {st }}$ century learner make sense of different listening genres, the social contexts in which they are used and make connections between the input and their own social contexts.

\section{b) Text authenticity and genuineness}

Authentic materials, such as newspapers and magazines, radio and TV broadcasts, or internet material, being spontaneous, natural and of diverse styles, are produced for non-pedagogical purposes (i.e., GILMORE, 2007; NUNAN, 1989). They thus "expose learners to language use[d] in real life, drawing their attention to features of [genuine speech -i.e., natural rhythm and intonation, natural starts and stops, incomplete sentences, hesitations and fillers] input (TOMLINSON, 2010, p. 83) satisfy[ing] their search for [world] knowledge (emphasis by the authors of this paper), "and allow[ing][them] to control their language use" (ROST, 2016, p. 155). Consequently, such materials are useful for improving the communicative aspects of the language. The above definitions though, not necessarily excluding NNSs tend to disregard the important and authentic forms and functions of English as a lingua franca (ALPTEKIN, 2002; GALLOWAY, 2017; GILMORE, 2007; TAN, 2005), mainly produced by NNs. In this study, by the term authenticity, we also refer to speech produced by NNs.

\subsubsection{Criterion 2: Communication strategies}

Exposure to a variety of communication strategies, such as repetition, paraphrasing, as well as self-and other repair moves, (COGO, 2009; JENKINS; COGO; DEWEY, 2011), directed towards the students who will have to cope with unfamiliar accents and language structures and will frequently negotiate the meanings expressed in their interactions, is important. As Louhiala-Salminen et al. (2005) note, "learners should be trained to see themselves as communicators, with real jobs to perform and needs to fulfil" 
(p. 419); it is the communication strategies employed then that should be emphasised for the successful accomplishment of these professional and personal needs and not the language forms (emphasis by the authors) the interactants use when communicating.

\subsubsection{Criterion 3: Encouragement of the use of English outside the school environment.}

Inputs and follow-up tasks included in coursebooks should promote learnerinteractions outside the school environment. As findings from relevant research show (NIKOLOV; MIHALJEVIC DJJIGUNOVIC, 2006; VETTORE, 2016), when young learners are engaged with communication outside their school environment, especially with peers from abroad, they can be positively motivated towards FL learning, develop their intercultural awareness and communication strategies, are offered opportunities for "languaging" (SEIDLHOFER, 2011) and become multiculturally competent communicators (LOPRIORE, 2015).

\subsubsection{Criterion 4: ELF/GE-awareness raising, (among the learners), through appropriately structured tasks. \\ ELF awareness is defined as, the process of engaging with ELF research and developing one's own understanding of the ways in which it can be integrated in one's classroom context, through a continuous process of critical reflection, design, implementation and evaluation of instructional activities that reflect and localize one's interpretation of the ELF construct. (SIFAKIS; BAYYURT, 2017, p. 459).}

According to the above definition, specifically designed tasks can lead learners to reflect upon language use, the listening input in this case, emphasizing the importance of effective communication and the communication strategies, for example, employed by speakers in the audio and "lead [them] to gradual transformation" helping them to turn into self-confident and successful language users (SEIDLHOFER, 2011).

On the basis of the above criteria we attempted to answer the questions below:

\section{Criterion 1: Direct or indirect exposure to aspects of GE as manifested through:} a) the variety of:

- topics/relevance,

i) Do the topics in the books reflect a wide range of global and intercultural issues?

ii) Are they interesting and relevant to the learners' needs and interests as justified above (in 4.2.1 (topics/relevance)?

- accents

i) Are $\mathrm{N}$ as well as NN accents present in the listening texts?

- genres

i) Is there a variety of genres reflecting different socio-cultural and professional settings?

\section{b) Text authenticity and genuineness}


i) Are the texts used produced in real life situations, displaying features of authentic and genuine speech?

ii) Do the texts enable listeners to further their language learning, that is:

- familiarise themselves with different text types exhibiting features of authenticity

( $\mathrm{N}$ and $\mathrm{NN}$ ) and genuineness (as described above), and

- eventually apply this knowledge in future communicative contexts?

\section{Criterion 2: Communication strategies:}

i) Were there any dialogues and activities enhancing real life communication in the follow up tasks?

ii) Do the dialogues embody any accommodation/negotiation strategies (i.e., speaker repetition, paraphrasing, as well as self-and other-repair and pre-emptive moves together with a co-operative exploitation of multilingual resources and repertoires (COGO, 2009; JENKINS; COGO; DEWEY, 2011), initiated to secure speaker understanding in case of misinterpretation (see KAUR, 2009) or solve the problem of non-understanding or miscommunication?

Criterion 3: Encouragement of the use of English outside the school environment.

i) Are there follow-up tasks/exchanges creating opportunities among learners' using English with other peers (Greek and non-Greek) living in Greece or any other country in the world?

Criterion 4: GE-awareness raising, (among learners), through appropriately structured tasks.

i) Do the input and tasks promote a more global aspect of English or do they instil inner -circle bound stereotypes and attitudes? In other words,

- do the inputs and subsequent questions lead learners to think about the language, language use and what is appropriate to multiple purposes?

- are learners given the opportunities to reconsider their norm-bound beliefs (SEIDLHOFER, 2011, p. 199) and made aware of the actual language usage as per their communicative interests?

\subsection{CORPUS OF THE COURSEBOOKS}

The main source of our corpus derived from the two students' coursebooks (B1 and B2) as the students' books "is the only source component used by many teachers around the world" (TOMLINSON; MASUHARA, 2013, p. 235). So, it is the main medium between teachers and learners.

For the analysis, we systematically examined all 9 units of each book, inputs, all follow-up tasks, activities, pronunciation practice, and vocabulary in context, within each unit. Accordingly, the instructions and tips in the teacher's books were also studied whereas the workbooks and further supplementary electronic materials available online on (http://ebooks.edu.gr/new/extra-resources.php?course=DSGYM-A111) were not considered. 


\subsection{FINDINGS: ANSWERS TO RESEARCH QUESTIONS}

Overall, the content of the listening material in the textbooks is satisfactorily connected with students' interests motivating them to respond positively to numerous inputs and the subsequent tasks. However, certain aspects of GE were not detected. More analytically and according to the stipulated criteria, we noticed the following:

\section{Criterion 1: Direct or indirect exposure to aspects of GE.}

It was observed that both textbooks contain a good range of topics which were carefully selected to reflect various socio-cultural issues appealing to teenagers coming from different socio-cultural/ethnic backgrounds. Listening texts in particular, focus on themes such as sports, animals, environmental issues, music bands, camp life, food and fashion, space programmes, celebrities, leisure time, Junior High School life, educational activities, history, travelling, cultural matters, seeking advice, shopping, attitudes/behaviour towards people, etc. All these are topics that adolescents can relate to (KOKKEVI et al, 2011) and, consequently, "can engage with and create discourse around for the purpose of furthering their language learning" (McKAY, 2012, p. 80). Besides, there are topics that aim at sensitising learners to serious world issues such as: natural disasters and accidents, voluntary work and teenage action for world/health problems, etc. So, the topics of audio material do reflect interesting and relevant-to the adolescents themes stemming from adolescents' daily reality and catering for their future world and professional needs in contemporary world.

Regarding aspects of GE, as manifested through speech varieties, we observed the following: in both textbooks, different speakers, including teenagers, claiming they come from different cultural/ethnic backgrounds, are heard using English. For example, pupils of various nationalities are in an international camp, visit schools, museums or embassies of different countries, exchange e-mails with other (e.g. Indonesian) students. However, it is rather unfortunate that in both coursebooks most accents are not simulating faithfully the nationality and culture they are supposed to. The Italian teenager, for example, in (B2/Unit 1, p. 1), has an English accent when he salutes in Italian and most importantly, his voice is easily recognisable as belonging to the main adult $(\mathrm{BrE})$ speaker who gives the rubrics and performs most of the audios. Similarly, in the audio of B2/U1, p. 3, the Italian teenage speaker, claimed to be the same as the one on B2/U1, p. 1 , has a notably different teenage voice trying to simulate an AmE accent. In some audios, a better effort is made to use native Greek speakers as the main speakers in the recording (e.g., B2/U6, lesson 3, p. 94), but unexpected 'oddities' do appear. For instance, the speaker in B2/U6, p.94) a supposedly Greek character-judging from his name-is a $\mathrm{N}$ British speaker, the rubrics provider and main speaker of all recordings. Similarly, in B1/U3, p. 28 (two friends, an Italian and a French, talking online about their leisure activities), both speakers' speech is a poor token of NN-French and Italian accents. Indeed, on most occasions, the listener is rather frustrated to hear predominantly the standard BrE accent and on some occasions, Greek-English although many topics (e.g., in $\mathrm{B} 2 / \mathrm{U} 7, \mathrm{p} .101$, e-friends from different countries are leaving phone messages to a 
magazine) constitute a fine chance to expose students to a variety of $\mathrm{NN}$ accents which correspond to the alleged international main characters introduced in the audios. This norm-bound dominance neither promotes learners' familiarization with the multiplicity of NN accents, nor their intercultural awareness to the use and importance of English as an international lingua franca.

We also observed that through monologues or dialogues, students are systematically familiarized with a variety of genres, namely, narratives (B2/U4, pp. 49 \& 51), songs (B2/U5, p. 79), interviews (B1/U5, p. 64), advertisements (B1/U1, p. 10) informal, telephone conversations among friends (B1/U, p. 111), etc. Reading of a word list, an unproductive and unreal talk, however, is not rare (i.e. B1/U3, U6, U7, U8; B2/U 5, p. 77, task 1]. The purpose of oral discourse is interactional and/or transactional.

Accents and genres are linked to text authenticity and genuineness. Authenticity is related to the notion of "realness", genuineness, real life language, be it N or NN speech (SIFAKIS, et al, 2004, p. 194). Due to the aforementioned problems in accents and unnatural discourse, authenticity is not successfully simulated and thus, most of the recordings can be characterised as rather scripted (e.g., B1/U5, U6, U7, U8] and B2/U5, p. 72, 73; U, p. 131] or to a limited extent, semi-scripted (e.g., B2/U6, p. 94). Furthermore, there are few features of genuineness (for instance, in B2/U1, p. 3 some background noise is heard), but on the whole, there exist no pauses, hesitations, false starts, repetitions, asking for clarification-with one exception in the interview (B1/U4, p. 53)-that would render the audios more natural and spontaneous.

\section{Criterion 2: Communication strategies}

Some follow-up tasks tend to have a more communicatively oriented purpose as they prompt students to connect with contemporary issues such as listening and talking about EU, [i.e., B2/ U9, p. 138] and express their opinions on topics they can relate such as animal protection $[\mathrm{B} 1 / \mathrm{U} 4$, p. 44 and p. 53), or writing articles for school newspapers [i.e., B2/U8, p. 117]. Topics as the ones above are introduced in the listening inputs. However, most of these follow-up tasks have a rather unclear outcome failing to make students conscious about what they are asked to do, what they are supposed to learn and transfer in their daily communications. In some cases, the lack of a communicative purpose is related to the form-oriented learning outcome of the tasks which aim at practicing, even drilling, learners' vocabulary, grammar and pronunciation (e.g., B1/U3, p. 28, task, 5; U2/p. 15, /s/vs / //; B2/U5; lesson 2, p. 72). So, students are far from getting assistance on enhancing their oracy skills that will need in their reality. Overall, even though some tasks could link with outside the classroom situations (e.g. B1/p. 28, task 4; p. 29, task 6, 7, 8; B2/U6, p. 73) and some communicative activities are attempted (i.e., B1[p. 29, task 8], B2[/U9, task 2, p. 138]), there is no further exploitation and connection with the real world and no promotion of students' communicative competencies. What's more, nowhere in the listening component of both coursebooks are there any interactions in which accommodation strategies (e.g., asking for clarification, paraphrasing, exploitation of any possible multilingual resource available to the learner, 
(COGO, 2009; JENKINS; COGO; DEWEY, 2011; SEIDLHOFER, 2011) were introduced. So, familiarisation and, eventually, acquisition of strategies which enable learners to deal with and solve issues of misunderstanding making them "autonomous" (KARAGIANNI, et al, 2008; p. ii;) and successful language users are rather neglected.

Criterion 3: Encouragement of the use of English outside the school environment at a local or global level.

Despite the motivating topics, the scripted and the poorly semi-scripted inputs, almost exclusively geared towards $\mathrm{N} /$ standard $(\mathrm{Br}) \mathrm{E}$ accent, tend to prevent the activation of $\mathrm{GE}$ as a useful tool of communication in international contexts where learners will soon be required to function. What's more, the subsequent tasks, remaining mainly at a superficial level, are not considered by learners as offering them "opportunities to use the target language to achieve a communicative purpose” (TOMLISON, 2010, p. 83). Even in some limited cases where there is some indirect reference to the international character of English (e.g., B2/U1, p. 5) or some promotion of local (Greek) and international context (e.g., B2/U4, p. 44), students do not become culturally aware of how the topic (using English words in Modern Greek and famous international personalities) could be of some use to their everyday life and link to GE.

Criterion 4: GE-awareness raising, (among learners), through appropriately structured tasks and questions.

As per the Sifakis \& Bayyurt, (2017) definition of ELF [GE]-awareness specifically designed tasks and activities should lead learners to reflect upon the language, make connections with their own contexts and realities, develop their understanding of the use of language and reconsider their attitudes towards adherence to "the standard codes and regulative conventions of ENL" (SEIDLHOFER, 2011, p. 199). On the contrary, the attitudes promoted are heavily geared towards inner circle-UK norms. Based on the above definition, we observe little effort, through questions and tasks, to raise language and metacognitive awareness of the language used. Pronunciation issues, for example, on the important features of different phonemes, such as [B1/U2, p. 15, /s/ vs / $/$ ] or stress patterns, (B1/U4, p. 52 and U5, p. 69; B2/U7, p. 113, task 4) and their associations with meaning differences don't go beyond the 'listen and repeat' or the 'tick' stage. So, such tasks attempt to improve only students" micro-skills and fail to "implicitly" or "explicitly" (KEMALOGLOU; BAYYURT, forthcoming) guide learners to reflect upon the importance or unimportance of the distinctive characteristics of language towards effective communication and make them aware of the actual language usage as per their communicative interests.

\section{TEACHING IMPLICATIONS AND CONCLUDING REMARKS}

The main target of this study was to explore whether aspects of GE are detected in the listening component of the books used in the $1^{\text {st }}$ grade of Greek lower secondary state school. Overall, we observed that there are some aspects of GE but there are still many areas that remain untraceable. 
In particular, issues of global concern through a variety of topics are observed in both coursebooks. This variety is linked to the target group interests and as such, it is expected to "stimulate intellectual, aesthetic and emotional involvement of the learners" (TOMLINSON, 2010, p. 83) and give them the opportunity to use language as a tool of pursuing "knowledge and information from different [...] areas" (CROSS-THEMATIC CURRICULUM FRAMEWORK FOR MODERN FOREIGN LANGUAGES, 2003, p. 145). Similarly, students are familiarised with different genres which they will need to cope with in their present and future encounters, "develop[ing eventually] their ability to use the language in real life situations in predictable or non-predictable settings" (ibid, 2003, p. 145).

When it comes to manifestations of GE aspects through accents, authentic and genuine texts though, we observed limited, simulated real life [authentic and genuine] discourse and dominance of standard BrE, with few exceptions where Native Greek English (NGE) is heard. These features are in contrast to the claims made in the teacher's book, as stated above in section 3. Promotion then of N, BrE in particular, and scripted speech, does not draw learners' attention to the international character of English. On the contrary, it still emphasizes accuracy rather than intelligibility, effective use of accommodation (COGO, 2009) and successful communication with interactants coming from countries of all three Kachruvian circles. Similarly, the lack of authentic texts, NN accents and interactions in which accommodation is observed, hampers considerably students' enhancement of intercultural skills, namely, "their capacity for adapting to different uses of English by creating comprehensible communication with a variety of NN as well as NSs (SIFAKIS; SOUGARI, 2004, p. 143).

Furthermore, it was shown that the inputs and the follow-up tasks are not structured in a critically reflected manner since several tasks are mechanical, form-oriented and not leading to changing attitudes and stereotypes towards "a move away from native English speaker expertise" to multi/trans-lingual and multi-cultural practices (GALLOWAY; ROSE, 2015, p. 206)

Consequently, due to the inadequacies of the listening inputs and tasks, it remains solely to the ELT teachers to create the conditions in order for learners to be exposed and ultimately, engaged to "the complex interactive situations" (SIFAKIS; SOUGARI, 2004, p. 146) of the $21^{\text {st }}$ century.

Since the latest ELT contexts are genuine GE contexts, it is fundamental that existing ELT materials, Think Teen in our case, be enriched to cover the demands of a global user for effective translingual and intercultural communication. Future users should be acquainted with the necessary compensatory' strategies, namely with strategies employed by learners in their attempt to seek for missing information, or clarification. Besides, students should be led towards critical reflection upon the diverse $\mathrm{E}$ accents, different from the ones they have been used to, which vary in their degree of intelligibility and familiarity. Inclusion, for example, of less intelligible accents will enhance learners' familiarity, comprehensibility and intercultural awareness as learners will realise the 
"widely diverse linguistic and communicative domains of EIL" (SIFAKIS; SOUGARI, 2004, p. 146).

Attempting to promote critical reflection and attitude change towards "which English and whose English" (PRODROMOU, 2001) and "what culture, which culture" (PRODROMOU, 1992), ELT practitioners, prior to planning their lessons and designing activities, should reflect upon:

- "What [they] want their students to learn from [specifically designed] activit[ies] and why.

- How [they]can create the conditions for learners to engage with a text and/or other learners to promote their language proficiency" (McKAY, 2012, p. 80)

- How they can lead (through purposefully designed activities and questions) their students to "pay attention to features of authentic input" (TOMLINSON, 2010, p. 83) and reflect upon the language input they are exposed to.

Questions leading students towards this reflection would turn around, for example, the difficulties or the eases students face when engaging with a specific text or a communicative situation, as well as the strategies they resort to in order to cope with the difficulties. Similarly, additional questions will have to do with the detection of possible localised linguistic forms that can be recognised in the inputs, or the identification of 'errors' in the language they are exposed to and to whether these errors affect the overall text understanding.

Ideas that can be used by the teachers in creating GE-oriented activities, enhancing students' awareness and addressing their needs abound in GE literature (i.e. FRIEDRICH, 2012; KOHN, 2016; KORDIA, forthcoming; LOPRIORE, 2016; SIFAKIS; SOUGARI, 2004; VETTOREL, 2010, 2016; CAVALHEIRO, et al, 2017)

Reflecting upon our findings, the GE research and the ample options ELT practitioners can resort to, we are offering an alternative of a listening lesson from $B 2$ and its adaptation in relation to the criteria set above. The recommended lesson and teaching material are created for a potentially multi-cultural (NG and other NNG) group, a reality in Greece nowadays, of the $1^{\text {st }}$ grade of Junior High School (B2/U5, lesson 2, p. 73) (Appendix A)

Our recommendation is driven by the problems connected with the limited authentic and genuine discourse and inclusion of accents other than $(\mathrm{Br}) \mathrm{E}$. Thus, the variety of topics introduced in both coursebooks offers 'lip service' to the students since most topics are socio-culturally decontextualized. Therefore, suggestions for modification of the existing input and tasks are offered so that the listening material can be overly or covertly linked with GE and hopefully, render learners more effective communicators, who will comfortably perceive and produce oral English, by liberating them from the fetters of N/standard (Br) English pronunciation and socio-cultural setting.

The selected listening material is on the stimulating but also culture-bound topic of superstitions. This topic could be more effectively exploited by drawing students' attention to the differences in the way various cultures perceive superstitions. The textbook's listening input includes Mrs Jones, a typical British speaker, who is interviewed by a $\mathrm{NBr}$ adult (the main speaker in the audios) and talks about superstitions in the UK. 
The input is non-authentic, non-genuine, (as per the definitions above). The recommended listening activities could be designed in a typical pre-/while-/post-listening sequence.

In the pre-listening (about 10 minutes) stage: the topic of superstitions could be introduced as described in Teacher's book, "Elicit that the pictures show superstitions. Ask students to describe the pictures \& elicit relevant vocabulary" (KARAGIANNI et al, 2008, p.73). This activity could motivate learners to activate their background knowledge on their own distinctive cultural characteristics, setting the ground for further follow-up class discussions.

While-listening stage: (modified input): the class teacher, a NNES, announces that the listening session is an interview between the teacher (interviewer) and 5 students. The teacher asks male and female adolescent students (interviewees) of different L1 cultural/ethnic backgrounds who want to speak lively in front of their classmates on what their native country regards as signs of bad luck. Each main interviewee considers the pictures that appear in the textbook and talks for approx. 2 min either totally spontaneously or from few notes they can prepare and have in front of them. [Interviewees' NN accent is noticeable but it is not expected to create problems in message understanding as the teacher has selected students who have a reasonably clear enunciation]. In order to achieve spontaneity and naturalness, interviewees are instructed to speak naturally so that some features of genuineness (hesitations, false starts, repetition, etc.) can emerge in their speech. In case there are only N Greek speakers(NGS) in the English classroom, the teacher/interviewer could ask some students who want to be interviewed to report any local Greek customs related to superstitions in their parents'/grandparents' hometown. Interviewees would be asked to refrain from asking the teacher questions related to vocabulary reminding them that this should be a simulated real-life interview. Yet, another choice would be that the English teacher produce a lively monologue on superstitions in different countries so that students would be at least indirectly exposed to multi-ethnic customs linked with superstitions.

The first textbook task is slightly revised as: "Which superstitions did your classmates talk about? Listen and tick the picture that corresponds to each superstition" "Did you hear any other superstitions that do not appear in the pictures? If yes, how many?' In this way, students get a first idea about superstitions in different countries and associate them with a picture but also with the speaker's (their classmate's) local accent. The second textbook task could also be modified to draw on GE: "Listen to your classmates who were interviewed once more and write good luck 'GL' or bad luck 'BL' and the country that each speaker refers to next to the pictures. You may add more signs of good or bad luck that you heard and the country they are linked with if they are not included in the pictures".

Post-listening stage (15 min)

Step 1: students_could be asked the following meta-cognitive questions to promote reflection on accent related matters and whether they needed to embark on any accommodation strategies in order to understand the message: "Which speaker was more 
difficult to understand and why?" "Do you frequently hear people using English with an audible NN accent?" "Do accents as such create any problems in your overall message understanding?"

Stage 2: Class presentation: In_this stage, students are given $5 \mathrm{~min}$ to prepare themselves and then, report in front of their colleagues the culture they were most impressed with, in reference to a superstition, and whether this superstition is different in their culture (i.e., black cats). Carrying out a whole-class discussion as such can trigger learners' interest towards intercultural differences and offer good opportunities for the employment of communication strategies.

Overall, in culture-related issues such as superstitions, class discussions among students of multicultural background help participants to share their own cultural distinctive characteristics but also to bring in their interactions several key elements of ELF/EIL communication. They introduce, for example, forms deviating from $\mathrm{N}$-speaker and will need to resort to accommodation strategies in order to maintain the flow of conversation. Following similar procedure might prove beneficial for the learners as they develop their intercultural awareness, their communicative and accommodation strategies employed in meaning negotiation and their sense that they are language users, rather than learners of the language.

Throughout these years, the discussions revolve around "whose culture, which language and whose language" we teach. It is about time we moved towards the acceptance that English is an International language and should be dealt with as such. Following Galloway (2017), we also believe that all relevant GE research and its connections with ELT

is not to establish a teachable model and to prescribe what should be taught in the ELT classroom. GE simply requires that we consider the learners' context and their needs when thinking about what target language to include. It is about increasing [our]choice[s] [in our ELT classrooms], not reducing [them]. (p. 476).

\section{REFERENCES}

ALPTEKIN, C. Towards intercultural communicative competence in ELT. ELT Journal, v. 56, n.1, p. 57-64, 2002.

AZA, A. Evaluating the writing component of the "Think-Teen" textbook from a socio-cognitive perspective. (Unpublished Master Thesis). Hellenic Open University, Patras, Greece, 2012.

BARRIOS, M. L., DE DEBAT, E. V.; TAVELLA, G. Materials in use in Argentina and the Southern Cone. In TOMLINSON B. (Ed.), English language learning materials: A critical review London: Continuum, 2008. p. 300-316.

BAYYURT, Y.; SIFAKIS, N.C. Developing an ELF-aware pedagogy. In. VETTOREL, P (Ed.), New Frontiers in Teaching and Learning English. Newcastle upon Tyne: Cambridge Scholars Publishing, 2015. p. 55-76. 
CALEFFI, P. ELF in the speaking and listening activities of recently published Englishlanguage coursebooks. In Lopriore, L \& Grazzi, E. (Eds.), Intercultural Communication: New perspectives from ELF. Rome: Roma'TrE-Press. 2016. p. 63-82.

CAVALHEIRO, L. Language and Teaching Materials in ELT: An EIL Approach. eTEALS: An ejournal of Teacher Education and Applied Language Studies, v. 4, p. 71-84, 2013.

CAVALHEIRO, L.; GUERRA, L.; PEREIRA, R. Identifying ELF-aware teaching practices in Portugal: a preliminary study. Paper presented at the $10^{\text {th }}$ International Conference of English as a Lingua Franca, University of Helsinki, Finland, 2017.

COGO, A. Accommodating difference in ELF Conversations: a study of pragmatic strategies. In MAURANEN, A. and RANTA, E. (Eds.), English as a Lingua Franca: Studies and Findings. Newcastle upon Tyne: Cambridge Scholars Press, 2009. p. 254-273.

COGO, A.; DEWEY, M. Analysing English as a Lingua Franca: a corpus-driven investigation. London: Continuum International Publishing Group, 2012.

COUNCIL OF EUROPE: Common European Framework of Reference for Languages 2001. Cambridge, CUP. [Online] Available from

http://www.coe.int/t/dg4/linguistic/CADRE_EN.asp [last accessed 26/08/17].

CROSS-CURRICULAR UNIFIED FRAMEWORK 2003. Pedagogical Institute. www.pi-schools.gr [last accessed 26/08/17].

CRYSTAL, D. Two thousand million?’ English Today, v. 24, n. 1, p. 3-6, 2008.

DENDRINOS, B. The EFL textbook and its ideology. Athens: Grivas Publications,1992.

FIRTH, A. The discursive accomplishment of normality. On "lingua franca" English and conversation analysis. Journal of Pragmatics, v. 26, p. 237-59, 1996.

FRIEDRICH, P. ELF, intercultural communication and the strategic aspect of communicative competence. In MATSUDA, A (Ed.) Principles and practices of teaching English as an international language. Bristol: Multilingual Matters, 2012. p. 44-54.

GALLOWAY, N.; ROSE, H. Using listening journals to raise awareness of Global Englishes in ELT. ELT Journal, v. 68, n.4, p. 386-396, 2014.

GALLOWAY, N.; ROSE, H. Introducing Global Englishes. Abingdon: Routledge, 2015.

GALLOWAY, N. ELF and ELT teaching materials. In. JENKINS, J; BAKER, W. AND M. DEWEY (Eds.) The Routledge Handbook of English as a Lingua Franca. Routledge, 2017. p. $486-480$.

GILMORE, A. Authentic materials and authenticity in foreign language learning. Language Teaching, v. 40, n. 2, p. 97-118, 2007.

GRADDOL, D. English Next. London: British Council, 2006. 
GRAY, J. The global coursebook in English language teaching. In. BLOCK D.; CAMERON, D (Eds.). Globalization and language teaching. London: Routledge, 2002. p. 151167.

GRAY, J. The construction of English: culture, consumerism and promotion in the ELT global coursebook. Basingtoke: Palgrave Macmillan, 2010.

HATZINIKOLAOU, N. The teaching of speaking in the EFL classes of Greek state junior high school. (Unpublished study). University of Essex, UK, 2014.

JENKINS, J. The phonology of English as an International Language. Oxford: OUP, 2000.

JENKINS, J. Current perspectives on teaching World Englishes and English as a lingua franca. TESOL Quarterly, v. 40, n 1, p. 157-181, 2006.

JENKINS, J. English as a lingua franca: attitude and identity. Oxford: OUP, 2007.

JENKINS, J.; COGO, A.; DEWEY, M. Review of developments in research into English as a lingua franca. Language Teaching Research, v. 44, n. 3, pp. 281-315, 2011.

KACHRU, B. B. The alchemy of English. The spread, functions and models of non-native Englishes. Oxford: Pergamon,1986.

KARAGIANNI, E.; KOUI, V.; NIKOLAKAKI, K. Think Teen: 1st Grade Junior High School Teacher's Book. Athens: National Book Center of Greece, 2008.

KAUR, J. English as a Lingua Franca. Co-constructing understanding. Saarbrücken: VDM Verlag, 2009.

KEMALOGLU-ER, E.; BAYYURT, Y. ELF-awareness in teaching and teacher education: Explicit and implicit ways of integrating ELF into the English language classroom. In. SIFAKIS N. C.; TSANTILA, N. (Eds.), ELF4EFL. Bristol, UK: Multilingual Matters, forthcoming.

KIRKPATRICK, A. Learning English and Other Languages in Multinlingual Settings: Myths and Principles. Available at: http://libdr1.ied.edu.hk/pubdata/img00/arch00/link/archive/1/instarh/3149_image.p df. Access on: 22 May, 2017.

KIRKPATRICK, A. Learning English and Other Languages in Multinlingual Settings: myths and Principles. 2009. Available at:

http://libdr1.ied.edu.hk/pubdata/img00/arch00/link/archive/1/instarh/3149_image.p df. Accessed on: 25 October, 2016.

KIVISTÖ, A. Accents of English as a lingua franca: A study of Finnish textbooks (Unpublished thesis). University of Tampere, Finland, 2005. Available at: http://www.helsinki.fi/englanti/elfa/ProGradu_Anne_Kivisto.pdf. Access on 18, June, 2016.

KOHN, K. Teaching towards ELF competence in the English classroom. In 
TSANTILA, N; MANDALIOS, J; ILKOS, M. (Eds.), ELF: Pedagogical and interdisciplinary perspectives. Athens: DEREE-The American College of Greece. 2016. p. 25-32.

KOKKEVI, A; FOTIOU, A. XANTHAKI, M.; KANAVOU, E. Adolescents' free time. Adolescents: behaviour and health. Athens: University research Institute of mental and emotional health, 2011. Available at: http://www.epipsi.gr/pdf/2011/06_HBSC_2010_EPIPSI_2011.pdf, Accessed on: 30, May, 2017.

KORDIA, S. ELF-aware teaching in practice: a teacher's perspective. In. SIFAKIS N. C.; TSANTILA, N. (Eds.), ELF4EFL. Bristol, UK: Multilingual Matters, forthcoming.

LOPRIORE, L. Young learners in EFL classrooms. A shift in perspective. In VETTOREL, P. (Ed). New frontiers in teaching and learning English. Newcastle upon Tyne: Cambridge Scholars Publishing, 2015. p. 159-177.

LOPRIORE, L. ELF in teacher education: A way and ways. In LOPRIORE, L; GRAZZI, E.(Eds.). Intercultural Communication: New perspectives from ELF. Rome: RomaTrE-Press. 2016. p. 167-187.

LOUHIALA-SALMINEN, L.; CHARLES, M.; KANKAANRANTA, A. English as a lingua franca in Nordic corporate mergers: two case companies. English for Specific Purposes, v. 24, n. 4, p. 401-421, 2005.

MATSUDA, A. International Understanding through teaching World Englishes. World Englishes, v. 21, n.3, p. 436-440, 2002a.

MATSUDA, A. Representations of users and uses of English in Beginning Japanese EFL textbooks. JALT Journal, v. 24, n.2, p. 182-200, 2002b.

MATSUDA, A. Teaching materials in EIL. In ALSAGOFF, L.; MCKAY, S.K; HU, G.; RENANDYA W.A (Eds.). Principles and practices for teaching English as an international language. New York/Abingdon: Routledge, 2012. p. 168-185.

MATSUDA, A. Preparing Teachers to Teach English as an International Language. Bristol: Multilingual Matters Ltd., 2017.

McDONOUGH, J.; SHAW, C.; MASUHARA, H. Materials and Methods in ELT: a Teacher's Guide (3 ${ }^{\text {rd }}$ ed.). Malden: Wiley-Blackwell, 2013.

McGRATH, I. Teaching materials and the roles of EFL/ESL teachers: practice and theory. London: Bloomsbury, 2013.

McKAY, S. L. Toward an appropriate EIL pedagogy: Re-examining common ELT assumptions. International Journal of Applied Linguistics, v. 13, n. 1, p.1-22, 2003.

McKAY, S. L. Researching Second Language Classrooms. New York: Routledge, 2006. 
McKAY, S.L. Teaching materials for English as an International Language. In. MATSUDA, A. (Ed.), Principles and practices of teaching English as an International Language Bristol: Multilingual Matters, 2012. p. 70-83.

MILLER, C. Genre as a social action. Quartely journal of speech, v. 70, p. 151-167, 1984.

MINISTRY OF EDUCATION, RESEARCH AND RELIGIOUS AFFAIRS.

Teaching of English per levels of competency. Government Gazette, 2/2732). Athens:

Greece. Available at: http://www.minedu.gov.gr/publications/docs2016/aggliki.pdf. Accessed on: 24 October, 2016.

MODIANO, M. Standard English(es) and educational practices for the world's lingua franca. English Today, v. 15, n.4, p. 3-13, 1999.

NIKOLOV, M.; DJJIGUNOVIC, M. Recent research on age, second language acquisition, and early foreign language learning. Annual Review of Applied Linguistics, v. 26, p. 234-260, 2006.

NUNAN, D. Designing tasks for the communicative classroom. Cambridge: CUP, 1989.

PARK, J. S.; WEE, L. A practice based critique as a lingua franca. World Englishes, v. 30, n.3, p. 360-374, 2011.

PRODROMOU, L. What culture? Which culture? Cross-cultural factors in language learning. ELT Journal, v. 46, n. 1, p. 39-50. 1992.

PRODROMOU, L. (2001). Prospero's books or which English, whose English? CAUCE, Revista de Filologia y su Didactica, v. 24, p. 583-615.

ROST, M. Teaching and researching listening (3 ${ }^{\text {rd }}$ ed.). New York: Routledge. 2016.

SHELDON, L. Evaluating ELT textbooks and materials. ELT Journal, v. 42, n.4, p. $237-$ 246, 1988.

SEIDLHOFER, B. Closing a conceptual gap: The case for a description of English as a lingua franca. International Journal of Applies Linguistics, v.11, n. 2, p. 133-158, 2001.

SEIDLHOFER, B. Research perspectives on teaching English as a Lingua franca. Annual Review of Applied Linguistics, v. 24, p. 209-239, 2004.

SEIDLHOFER, B. Of norms and mindsets. Australian Review of Applied Linguistics, v.31, $n$. (3), p. 331-337, 2008.

SEIDLHOFER, B. Understanding English as a lingua franca. Oxford: OUP, 2011.

SIFAKIS, N. C. Teaching EIL-teaching international or intercultural English: what teachers should know. System, v. 32, n. 2, p. 237-50, 2004.

SIFAKIS, N. C. ELF awareness in English Language Teaching: principles and processes. Applied linguistics, amx034, https://doi.org/10.1093/applin/amx034, 2017. 
SIFAKIS, N. C.; BAYYURT, Y. ELF-aware teacher education and development. In JENKINS, J.; BAKER, W.; DEWEY, M. (Eds.). The Routledge Handbook on English as a Lingua Franca. London: Routledge, 2017. p. 456-467.

SIFAKIS, N. C.; GEORGOUNTZOU, A; HILL, M. Language Learning Skills and Materials: oracy and literacy, v.1. Patras: Hellenic Open University. 2004.

SIFACIS, N. C.; SOUGARI, A. M. Language teaching as culture-bound pedagogy: setting the criteria for the designing of an EIL course. In DOKOU, C.; MITSI, E.; MITSIKOPOULOU, B. (Eds.). The periphery viewing the world: Selected papers from te 4rth international conference of the Hellenic association for the study of English. Parousia publications 60, Athens, 2004. pp. 141-149.

SIFAKIS, N. C.; SOUGARI, A.-M. Pronunciation Issues and EIL Pedagogy in the Periphery: a Survey of Greek State School Teachers' Beliefs. TESOL Quarterly, v. 39, n.3, p. 467-488, 2005.

SIQUEIRA, D. S. P. English as a Lingua Franca and ELT Materials: is The"Plastic World" really melting? In BAYYURT, Y.; ACKAN, S. (Eds.). Current perspectives on pedagogy for English as a lingua franca. Berlin: De Gruyter Mouton, 2015. p. 239-257.

TAKAHASHI, R. English as a Lingua Franca in a Japanese context: an analysis of ELF-oriented features in teaching materials and the attitudes of Japanese teachers and learners of English to ELForiented materials. (Unpublished doctoral dissertation). University of Edinburgh, Edinburgh, UK, 2011. Available at: https://www.era.lib.ed.ac.uk/handle/1842/5269. Accessed on 12, Aug, 2016.

TAN, M. Authentic language or language errors? Lessons from a learner corpus. ELT Journal, v. 59, n. 2, p. 126-34, 2005.

TOMLINSON, B. Developing Materials for language teaching. London: Continuum, 2003.

TOMLINSON, B. Principles of effective materials development. In HARWOOD, N. (Ed.). English language teaching materials: theory and practice. Cambridge: CUP, 2010. p. 81-108.

TOMLINSON, B.; MASUHARA, H. Adult coursebooks. ELT Journal, v. 67, n. 2, p. 233249, 2013.

TSAGARI, D.; SIFAKIS, N.C. EFL coursebook evaluation in Greek primary schools: views from teachers and authors. System, v. 45, p. 211-225, 2014.

VANDERGRIFT, L.; GOH C.M C. Teaching and Learning Second Language Listening: metacognition in Action. New York: Routledge, 2012.

VETTOREL, P. EIL/ELF and representation of culture in textbooks: only food, fairs, folklore and facts? In GAGLIARDI, C.; MALEY, A. (Eds.). EIL, ELF, Global English: Teaching and Learning Issues Bern: Peter Lang, 2010. p. 154-185. 
VETTOREL, P. New frontiers in teaching and learning English. Newcastle upon Tyne: Cambridge Scholars Publishing, 2015.

VETTOREL, P. Young learners' uses of ELF: moving beyond the classroom walls'. In Lopriore L.; Grazzi, E. (Eds.). Intercultural communication: new perspectives from ELF. Rome: Roma'Tre-Press, 2016. p. 83-107.

VETTTOREL, P.; LOPRIORE, L. Is there ELF in ELT coursebooks? Studies in second language learning and teaching, v. 3, n. 4, p. 483-504, 2013.

VET'TOREL, P.; LOPRIORE, L. WE, EIL, ELF and awareness of their pedagogical implications in teacher education programs in Italy. In MATSUDA, A (Ed.). Preparing Teachers to Teach English as an International Language. Bristol: Multilingual Matters Ltd., 2017. p. 197-209.

\section{APPENDIX}

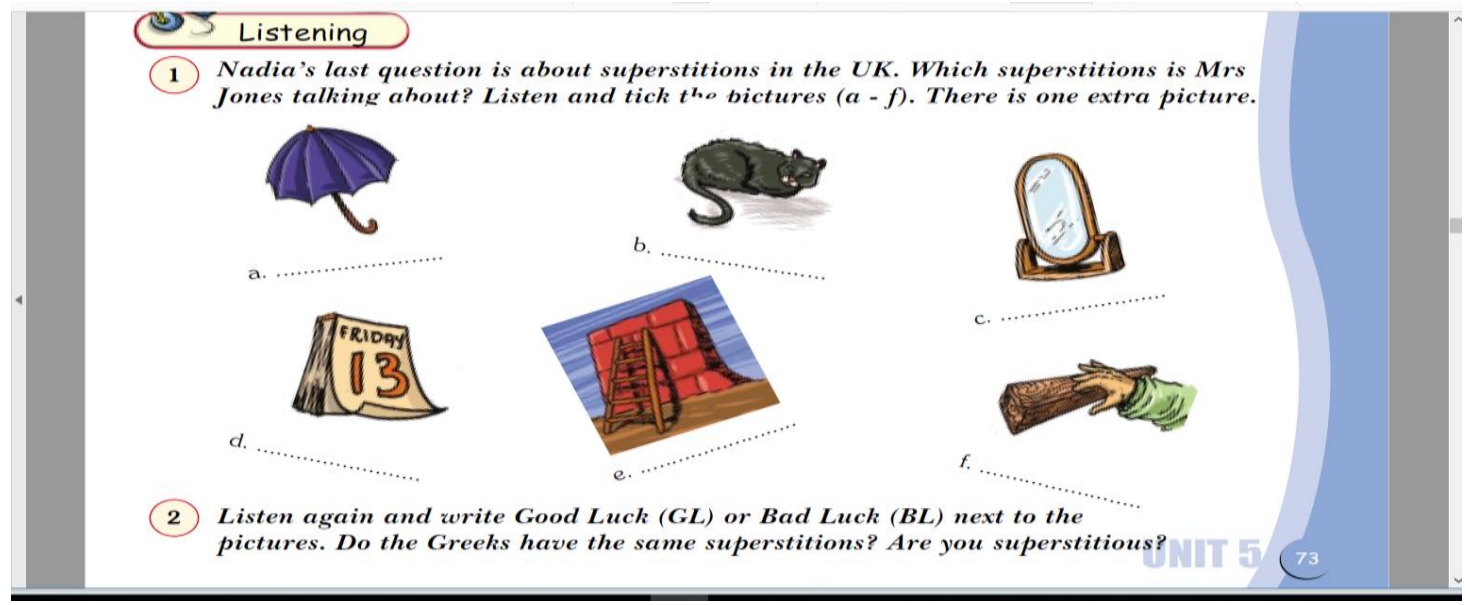

Recebido em: 15/08/2017

Aprovado em: 26/11/2017

Publicado em: 30/12/2017 